\title{
Disentangling the effect of viruses and nanoflagellates on prokaryotes in bathypelagic waters of the Mediterranean Sea
}

\author{
Serena Fonda Umani ${ }^{1, *}$, Elisa Malisana ${ }^{1}$, Francesca Focaracci ${ }^{1}$, Mirko Magagnini ${ }^{2}$, \\ Cinzia Corinaldesi ${ }^{2}$, Roberto Danovaro ${ }^{2}$ \\ ${ }^{1}$ Department of Life Sciences, University of Trieste, v. Valerio 28/1, 34127 Trieste, Italy \\ ${ }^{2}$ Department of Marine Science, Polytechnic University of Marche, Via Brecce Bianche, 60131 Ancona, Italy
}

\begin{abstract}
Bathypelagic ecosystems depend on prokaryotic heterotrophic biomass fuelled by vertical particulate organic matter (POM) fluxes, but very little information is available on the interactions among viruses, prokaryotes and nanoflagellates in deep waters. We simultaneously investigated the relative importance of the viral and heterotrophic nanoflagellate (HNF) grazing-induced prokaryotic mortality in bathypelagic waters by means of dilution experiments performed on samples collected at $1500 \mathrm{~m}$ depth from the Atlantic Ocean to the Eastern Mediterranean Sea. Prokaryotic abundance (range: 1.4 to $8.9 \times 10^{4}$ cells ml $^{-1}$ ), although different from one station to another, was on average not significantly different among biogeographic regions. The potential predators of prokaryotes (viruses, HNF and microzooplankton) followed a similar spatial pattern. Viruses were responsible for an important fraction of prokaryotic mortality (on average $13.4 \% \mathrm{~d}^{-1}$ ). Dilution experiments carried out to estimate the potential predation of HNF suggested a high effect on prokaryotic abundance. However, since the latter experiments also include the effect of viruses on prokaryotes, when this factor was disentangled from the overall mortality, the potential rates of HNF predation on prokaryotes (on average $49.5 \%$ ) were ca. 4 times higher than the effect due to viral infections. Conversely to patterns of distribution, the relative importance of virus-mediated mortality vs. HNF predation changed significantly among different regions. Results should be treated with caution due to the intrinsic difficulty in reproducing experimentally natural deep-sea conditions, but they permit disentangling of the relative effect of viruses and HNF on prokaryotes and compare the potential predatory control in different biogeographic regions.
\end{abstract}

KEY WORDS: Virioplankton - Prokaryotes · Heterotrophic $\cdot$ Nanoplankton · Microzooplankton · Bathypelagic waters $\cdot$ Mediterranean Sea

\section{INTRODUCTION}

The bathyal systems (ranging from 1000 to $4000 \mathrm{~m}$ depth) comprise $>144 \times 10^{6} \mathrm{~km}^{3}$ seawater (accounting for $70 \%$ of the total volume, Nagata et al. 2010), and represent a large proportion of the global biosphere. Despite its huge dimensions, this dark portion of the oceans is almost completely unexplored in terms of microbial food webs. Generally, prokaryotic abundance and biomass production decline by about 2 to 3 orders of magnitude from the surface to the bathypelagic water layers (Reinthaler et al. 2006). Deep-sea heterotrophic prokaryotes (HP; including both Bacteria and Archaea) largely depend on the flux of POM, which is utilized to build up most of the biomass produced in the aphotic zone (i.e. bottom-up controlled: Herndl et al. 2008, Aristegui et al. 2009, Nagata et al. 2010). Recent studies conducted in bathyal systems suggest that microbial communities and their interactions could be different from those known for surface 
waters (Herndl et al. 2008). Bathypelagic water apparently harbours a simpler food web than that present in surface waters (Pakhomov \& Perissinotto 1997). Direct estimates of grazing and virus-induced lysis have shown that predation can be responsible for a significant fraction of prokaryotic mortality in surface waters (Gasol \& Vaqué 1993, Pedros-Alio et al. 2000, Wommack \& Colwell 2000, Pernthaler 2005). Apparently the relative contribution of viral lysis and grazing to bacterioplankton mortality changes with depth (Weinbauer \& Höfle 1998a,b). Recent findings reported a 'HP:flagellate abundance' ratio (PFR) higher in depth than in surface (Aristegui et al. 2009) and a 'virus:HP abundance' ratio (VPR) increasing up to 10 times moving from the euphotic down to the bathypelagic zone (Magagnini et al. 2007, Parada et al. 2007), but data reported for different biogeographic regions are very contrasting. Following Aristegui et al. (2009) there are no significant changes of VPR with depth. Aristegui et al. (2009) argued that the microbial food web of the dark ocean might be highly dynamic, and hence prokaryote predators could play an important role. They suggested that HNF might control prokaryotic abundance in the meso-bathypelagic systems in the same way as in epipelagic water. As one of the major needs, Aristegui et al. (2009) identify the study of the interactions among viruses, HP and HNF that have not yet been synoptically investigated. To close this gap we investigated the interactions among viruses, HP, and HNF in seawater samples collected at 9 bathypelagic stations from the Atlantic Ocean to the Eastern Mediterranean Sea, and evaluated the effect of HNF grazing and viral infection on HP mortality for the first time with incubation-based experiments.

\section{MATERIALS AND METHODS}

Study area and sampling. Sampling was carried out across the entire Mediterranean basin using the RV 'Urania' (Atlantic Ocean \& western Mediterranean) and RV 'Universitatis' (eastern Mediterranean) within the framework of the National Project VECTOR from May 26 to June 27, 2007. The Mediterranean Sea is a unique system because of its permanent homeothermy below 200 to $300 \mathrm{~m}$ with warm deep waters (13 to $14^{\circ} \mathrm{C}$ ). It is characterised by strong climatic and trophic gradients as illustrated by the primary production ranging from $502.7 \pm 342.2$ (in the western sector) to $151 \pm 91.6 \mathrm{mg} \mathrm{C} \mathrm{m}^{-2} \mathrm{~d}^{-1}$ (eastern sector; Turley et al. 2000). All presented data are means \pm SD. Water samples were collected in the bathypelagic zone (at $1500 \mathrm{~m}$ depth) at 9 stations located along a west-east transect from the Atlantic Ocean to the Aegean Sea (Fig. 1, Table 1). Hydrological casts and water samplings were performed using a SBE 9/11 Plus CTD (equipped with 2 sensors for temperature, conductivity, oxygen, light transmission, fluorescence, $\mathrm{pH}$ ) coupled with a SBE 32 rosette sampler (carrying 12 Niskin bottles of $5 \mathrm{l}$ each). Temperature and conductivity sensors were calibrated before and after the cruise at the SACLANTCENTRE of La Spezia (Italy). During the cruise, the CTD temperature was controlled by means of 2 SIS RTM 4200 digital reversing platinum thermometers and with an Autosal Guildline 8400b model Salinometer (Table 1).

Viral counts, production and viral shunt. Viral counts were carried out as described by Patel et al. (2007) without previous fixation to avoid underestimations of viral abundances (Danovaro et al. 2001, Wen et

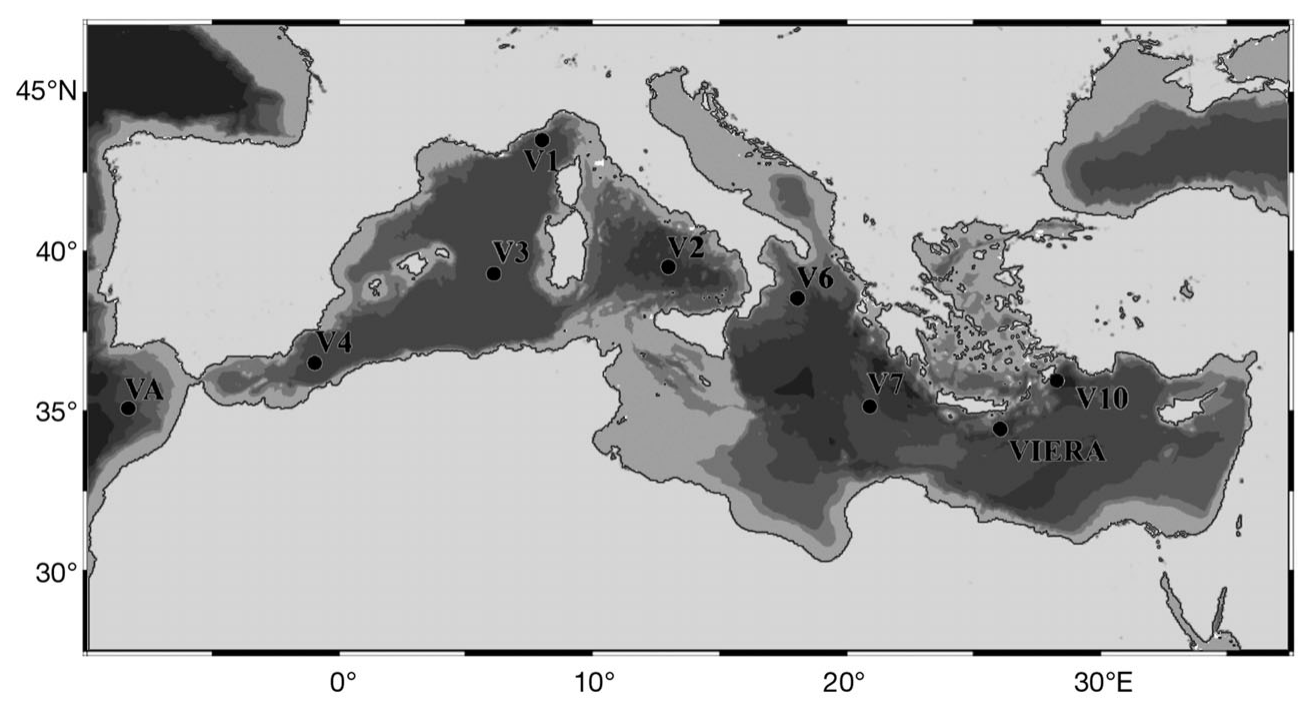

Fig. 1. Location of the 9 sampled stations from the Atlantic Ocean (VA) to the eastern Mediterranean Sea (V10) 
Table 1. Sampled stations (Stn): Latitude, longitude, salinity and temperature at the sampling depth $(1500 \mathrm{~m}$ for all stations)

\begin{tabular}{|lcccc|}
\hline Stn & $\begin{array}{c}\text { Latitude } \\
\left({ }^{\circ} \mathrm{N}\right)\end{array}$ & $\begin{array}{c}\text { Longitude } \\
\left({ }^{\circ} \mathrm{E}\right)\end{array}$ & Salinity & $\begin{array}{c}\text { Temp. } \\
\left({ }^{\circ} \mathrm{C}\right)\end{array}$ \\
\hline VA & $34^{\circ} 59.984^{\prime}$ & $-08^{\circ} 19.966^{\prime}$ & 35.63 & 7.2 \\
V4 & $36^{\circ} 30.137^{\prime}$ & $-00^{\circ} 59.850^{\prime}$ & 38.50 & 12.85 \\
V3 & $39^{\circ} 18.840^{\prime}$ & $06^{\circ} 0.392^{\prime}$ & 38.47 & 12.85 \\
V1 & $43^{\circ} 29.989^{\prime}$ & $08^{\circ} 00.000^{\prime}$ & 38.49 & 12.92 \\
V2 & $39^{\circ} 29.992^{\prime}$ & $12^{\circ} 59.953^{\prime}$ & 38.58 & 13.1 \\
V6 & $38^{\circ} 31.700^{\prime}$ & $18^{\circ} 02.160^{\prime}$ & 38.75 & 13.5 \\
V7 & $35^{\circ} 08.010^{\prime}$ & $20^{\circ} 53.900^{\prime}$ & 38.75 & 13.6 \\
VIERA & $34^{\circ} 24.430^{\prime}$ & $26^{\circ} 04.940^{\prime}$ & 38.76 & 13.6 \\
V10 & $35^{\circ} 56.810^{\prime}$ & $28^{\circ} 19.030^{\prime}$ & 38.76 & 13.63 \\
& & & & \\
\hline
\end{tabular}

al. 2004, Helton et al. 2006). At each site 3 independent samples were collected. After collection, samples were immediately frozen and stored at $-8^{\circ} \mathrm{C}$ until laboratory analyses. For slide preparation, sub-samples (300 to $1000 \mu \mathrm{l}$, depending on the expected viral abundance) were filtered in triplicate by means of $0.02 \mu \mathrm{m}$ Anodisc filters and immediately stained with $20 \mu \mathrm{l}$ SYBR Gold (stock solution diluted 1:5000; Chen et al. 2001). Filters were incubated in the dark for 15 min and mounted on glass slides with $20 \mu \mathrm{l}$ of sterile antifade $(50 \%$ phosphate buffer, $6.7 \mathrm{mM}$, pH 7.8, 50\% glycerol containing $0.5 \%$ ascorbic acid). Slides were stored at $-20^{\circ} \mathrm{C}$ until epifluorescence microscopy analyses (Zeiss Axioplan, magnification $1000 \times$ ). Viral counts were obtained by examining at least 10 fields, i.e. at least 200 viruses per replicate.

Viral production was determined by the dilution technique (Wilhelm et al. 2002), with some modifications. Three water samples $(50 \mathrm{ml})$ were transferred in Whirl-Pak bags, mixed with $100 \mathrm{ml}$ of virus-free ( $0.02 \mu \mathrm{m}$ pre-filtered by means of sterile Anotop filters) seawater, and incubated in the dark. Four subsamples $(10 \mathrm{ml})$ were collected: at the onset of incubation, and after 2,4 , and $6 \mathrm{~h}$, i.e. at $t_{0}, t_{2}, t_{4}, t_{6}$. Viral production rates were determined by a linear regression model, based on the following equation: $y=a x+b$ where $y$ is the viral abundance per $\mathrm{ml}$ of seawater, and $x$ is the incubation time expressed in hours, quantifying the increase in viral abundance over time following dilution of sample with virus-free water (Mei \& Danovaro 2004). The idea behind this approach is that by reducing viral and host densities, the occurrence of new infections is also reduced. At the same time, sample dilution renders almost negligible the effect of protozoan predation on viruses, and reduces viral losses due to enzymatic degradation. As an advantage, temporal changes in viral abundance can be directly estimated without using conversion factors (Wilhelm et al. 2002). Viral turnover rates were estimated by dividing viral production rates by viral abundance. The virusinduced prokaryotic mortality (VIPM) was calculated as follows:

$$
\begin{gathered}
\operatorname{VIPM}\left(\% \mathrm{~h}^{-1}\right)= \\
{\left[\mathrm{VP} \times \mathrm{BS}^{-1} \times(\text { prokaryotic abundance })^{-1}\right] \times 100}
\end{gathered}
$$

where VP is the viral production (expressed as viruses $\mathrm{ml}^{-1} \mathrm{~h}^{-1}$ ); BS is the burst size (i.e. the number of viruses released during cell lysis, expressed as viruses cell ${ }^{-1}$ ); the prokaryotic abundance is expressed as cells $\mathrm{ml}^{-1}$. We used a burst size value of 34 reported for bathypelagic waters (Weinbauer et al. 2003).

Prokaryote abundance and biomass. To assess HP abundances we used 3 samples that correspond to the initial concentration of HP in both viral shunt and grazing experiments. HP abundances were determined using epifluorescence microscopy. Two stains were tested: 4,6-diamidino-2-phenylindole (DAPI, Sigma) and SYBR Gold.

For DAPI staining, at each station 3 samples $(10 \mathrm{ml}$ each) were fixed with borate-buffered formalin $(2 \%$ final conc., prefiltered through a $0.2 \mathrm{~mm}$ Acrodisc filter) and preserved in the dark at $\sim 4^{\circ} \mathrm{C}$ until laboratory analyses. For HP counts, subsamples were filtered in triplicate onto $0.2 \mu \mathrm{m}$ black-stained polycarbonate filters (Nuclepore) and stained with DAPI (1 $\mathrm{mg} \mathrm{ml}^{-1}$ final conc., 15 min; Porter \& Feig 1980). Filters were mounted on microscope slides using non-fluorescence oil (Olympus) and stored at $-20^{\circ} \mathrm{C}$. HP enumeration was carried out using an Olympus epifluorescence microscope (BX 60 F5 with a HPO 100W/2 high-pressure mercury burner) at $1000 \times$ magnification under UV excitation light (BP 330 to $385 \mathrm{~nm}, \mathrm{BA} 420 \mathrm{~nm}$ ). A minimum of 300 cells was counted per filter (typically in 20 to 100 randomly selected fields).

For SYBR Gold staining, other 3 samples (generally $1.0 \mathrm{ml}$ each) were filtered in triplicate by means of $0.02 \mu \mathrm{m}$ Anodisc filters and immediately stained with $20 \mu \mathrm{l}$ SYBR Gold (stock solution diluted 1:5000, Chen et al. 2001). Filters were incubated in the dark for $15 \mathrm{~min}$ and mounted on glass slides with $20 \mu \mathrm{l}$ of sterile antifade (50\% phosphate buffer, $6.7 \mathrm{mM}, \mathrm{pH} 7.8$, $50 \%$ glycerol containing $0.5 \%$ ascorbic acid). Slides were stored at $-20^{\circ} \mathrm{C}$ until microscopic analysis. Cell counts were obtained by epifluorescence microscopy (Zeiss Axioplan, magnification $1000 \times$ ) by examining at least 20 fields. A total of 6 samples (3 each for viral shunt and grazing experiments) in triplicates were counted at each site. Cell numbers were converted into carbon biomass using a factor of $10 \mathrm{fg} \mathrm{C}^{\mathrm{C}} \mathrm{cell}^{-1}$ (Reinthaler et al. 2006).

HNF abundance and biomass. At each site 3 independent water samples (250 ml each) for HNF counts were immediately fixed with glutaraldehyde (final conc. $1 \%$ ), and kept in the dark at $\sim 4^{\circ} \mathrm{C}$ until further 
processing in the land laboratory. Abundances were determined using epifluorescence microscopy after DAPI staining (as above). Subsamples (30 to $40 \mathrm{ml}$ ) were filtered onto $0.8 \mu \mathrm{m}$ black-stained polycarbonate filters (Nuclepore). Filters were mounted on microscope slides, between layers of non-fluorescent immersion oil (Olympus), and counted within a few hours using an Olympus epifluorescence microscope (as above) at $1000 \times$. For counts to be considered significant, at least 100 to 150 fields per sample of each replicate had to be counted.

HNF biomasses were estimated by measuring the linear dimension and equating shapes to spheres; the resulting volumes were transformed into organic carbon values by using the conversion factor of $183 \mathrm{fg} \mathrm{C}$ $\mathrm{mm}^{-3}$ (Caron et al. 1995). HNF were divided into 3 size classes: $<3,3-5 \& 5-10 \mu \mathrm{m}$.

Microzooplankton abundance and biomass. For microzooplankton (MCZ) analyses, an aliquot of 51 was slowly and gently poured through a $10 \mu \mathrm{m}$ mesh Nitex screen to obtain samples of $250 \mathrm{ml}$, which were fixed with $4 \% \mathrm{Ca}\left(\mathrm{HCO}_{3}\right)_{2}$ buffered formaldehyde. Filtration through a $10 \mu \mathrm{m}$ screen was used to avoid any overlapping between the heterotrophic microplankton and nanoplankton, which could result in an overestimation in terms of the carbon content of the microzooplankton fraction. Concentration of large volume samples is a normal procedure when there is the need to reduce sample and fixative volumes (e.g. Buck et al. 1992, Fonda Umani et al. 2005a, Dolan et al. 2007). Subsamples (50 to $100 \mathrm{ml}$ ) were examined in a settling chamber, after the appropriate sedimentation time (calculated as $1 \mathrm{~cm} \mathrm{~h}^{-1}$ ) using an inverted microscope (Leitz Labovert, 200×) according to Utermöhl (1958). The entire surface of the chamber was examined, which corresponded to between 1 and 21 of the original sample. Tintinnid species were identified after Jörgensen (1924), Kofoid \& Campbell (1929), Marshall (1969), and Rampi \& Zattera (1982).

MCZ biomasses were estimated by measuring the linear dimension of each organism with eyepiece scale and equating shapes to standard geometric figures; the resulting volumes were transformed into organic carbon values by using the following conversion factors: tintinnids pg $\mathrm{C}=\mu^{3} \times 0.053+444.5$ (Verity \& Langdon 1984); ciliates (other than tintinnids), radiolarians, metazoan eggs, thecate dinoflagellates pg $C=\mu m^{3} \times$ 0.14 (Kiørboe et al. 1985, Putt \& Stoecker 1989, Lessard 1991); heterotrophic athecate dinoflagellates pg $\mathrm{C}=$ $\mu^{3} \times 0.13$ (Lessard 1991); and micrometazoans pg $\mathrm{C}=$ $\mu^{3} \times 0.08$ (Beers \& Stewart 1970). Bathypelagic samples used in this study are part of a larger set collected at the same stations at 3 more depths (surface, deep chlorophyll maximum, and near the bottom; data not shown). Biovolumes used here are means obtained by measuring at least 100 individuals or all of the organisms encountered when their abundance was lower.

HNF grazing rates on HP. We used the dilution protocol of Landry \& Hassett (1982) to estimate HNF bacterivory, because other methods, such as fluorescently labelled bacteria (FLB) (Sherr et al. 1987), minicells (Pace et al. 1990) or selective protist inhibition (Caron et al. 1991) do not allow investigating synoptically the relative importance of grazing vs. viral shunt in natural prokaryote assemblages. Advantages and disadvantages of the dilution method have been extensively debated over the last 20 yr (see Bamstedt et al. 2000, Strom 2000, Caron 2001, Jürgens \& Massana 2008 and references therein). However the dilution protocol has been widely used to assess both MCZ and HNF bacterivory (e.g. Tremaine \& Mills 1987, Lessard \& Murrell 1998, Murrell \& Hollibaugh 1998, Worden \& Binder 2003, Berninger \& Wickham 2005, Troussellier et al. 2005, Yokokawa \& Nagata 2005, Agis et al. 2006) over wide oceanic environments. Moreover, the dilution approach has been recently utilised by Taira et al. (2009) to provide simultaneous estimates of the viral lysis and HNF grazing over bacteria. The dilution method relies on the modulation of the contact rates between predators (HNF) and prey (HP). To create a dilution series, increasing proportions of pre-filtered seawater are added to natural water samples. Grazing rate is then estimated as the increase in apparent prey growth rate (i.e. HP abundance over time) with increasing dilution (i.e. decreasing HNF abundance). Predator grazing rates are calculated from the slope of the regressions of the apparent HP growth rate at different dilutions vs. the dilution factor. Growth rate of the HP is estimated as apparent growth rate extrapolated to $100 \%$ dilution (i.e. growth in the absence of grazers; Dolan \& McKeon 2005). This approach requires 4 main assumptions: (1) the growth and mortality rates may change over short-time scales, thus allowing the calculation of the average rates over the utilised incubation periods (i.e. ca. $24 \mathrm{~h}$ ); (2) the mean specific growth rate of HP is assumed to be constant (i.e. density independent; this latter assumption requires that dissolved organic nutrients do not limit all treatments); (3) the average clearance rate of individual consumer is assumed to be constant at all dilutions; (4) ingestion rates of the grazers are directly related to the prey density. Change in the abundance of the prey, $C$, over time $(t)$, can be represented by the following equation:

$$
C_{t}=C_{0} \mathrm{e}^{(k-G) t}
$$

where $C_{0}$ and $C_{t}$ are the initial and final carbon biomass of the prey, respectively, and $k$ and $G$ are apparent growth coefficient of the prey and grazing mortality, respectively. Ingestion $(I)$ was calculated as $I=G$ $C_{\mathrm{m}}$, where $C_{\mathrm{m}}$ is the average carbon concentration during the incubation. 
Deep-water samples were collected at $1500 \mathrm{~m}$ depth using a Rosette sampler with Niskin bottles. Immediately after retrieval on board the samples were gently transferred into 51 polypropylene carboys by siphoning through a $10 \mu \mathrm{m}$ mesh to remove MCZ. This filtration step might lead to the enrichment in labile DOC in the experimental bottles due to the shear stress on cells during filtration that causes protozoan cell lysis (Tremaine \& Mills 1987). Equipment used for the experiments was pre-treated with $10 \% \mathrm{HCl}$, and thoroughly rinsed with deionised water. Only pre-cleaned and rinsed silicone tubing was used. The particle-free fraction was obtained by using sterile in-line filters with $0.1 \mu \mathrm{m}$ Durapore membranes (Millipore). All parts of the filtration apparatus in contact with the water were made of Teflon. Nitex gloves were worn during the experimental set-up. Three sets of 4 serial dilutions $(20,50,80$, and $100 \%$ of whole water) were prepared in 21 graduated polycarbonate cylinder, gently mixed, and incubated in $175 \mathrm{ml}$ polycarbonate bottles. Experimental bottles were filled within $<1 \mathrm{~h}$ of sample collection. We maintained the water in the dark and at the in situ temperature during the preparation of the dilutions and the incubations. The incubations lasted $24 \mathrm{~h}$, but were conducted at $1 \mathrm{~atm}$ normal pressure. For each $t_{0}$ and $t_{24}$ samples we counted 3 replicates for HP at the epifluorescent microscope.

\section{RESULTS}

\section{Viral and prokaryotic abundance}

Viral and HP abundances in bathypelagic waters did not display a clear spatial pattern (Table 2, Fig. 2). For both variables significant differences were observed among stations (ANOVA, $\mathrm{p}<0.001)$. Viral abundance ranged from $2.86 \pm 0.28$ (Stn V1, Ligurian Sea) to $11.89 \pm 2.11 \times 10^{4}$ viruses $\mathrm{ml}^{-1}$ (Stn V2, southern Tyrrhenian Sea). HP abundance ranged from 1.31 $\pm 0.07 \times 10^{4}$ (Stn V7, open Eastern Mediterranean) to $8.98 \pm 0.19 \times 10^{4} \mathrm{HP} \mathrm{ml}^{-1}$ (Stn V2). At $1500 \mathrm{~m} \mathrm{depth}$ viral and HP abundances in the western Mediterranean were statistically not different from those mea-

Table 2. Virus abundance, abundance of prokaryotes stained by SYBR Gold, 'virus:prokaryote' ratio (VPR), viral production (VP), abundance of prokaryotes stained by DAPI, and nanoplankton abundance from all samples and stations (Stn)

\begin{tabular}{|c|c|c|c|c|c|c|c|c|c|c|}
\hline \multirow[t]{2}{*}{ Stn } & \multicolumn{2}{|c|}{ Viruses } & \multicolumn{2}{|c|}{ Prokaryotes SYBR Gold } & \multirow[t]{2}{*}{ VPR } & \multicolumn{2}{|c|}{ Viral production } & \multicolumn{2}{|c|}{ Prokaryotes DAPI } & \multirow{2}{*}{$\begin{array}{c}\mathrm{HNF} \\
\text { (cells ml }^{-1} \text { ) }\end{array}$} \\
\hline & $10^{4} \mathrm{ml}^{-1}$ & $\mathrm{SD}$ & $10^{4}$ cells ml -1 & $\mathrm{SD}$ & & $10^{4}$ virus $\mathrm{ml}^{-1} \mathrm{~h}^{-1}$ & $\mathrm{SD}$ & $10^{4}$ cells ml ${ }^{-1}$ & $\mathrm{SD}$ & \\
\hline \multirow[t]{3}{*}{ VA } & 3.32 & 0.12 & 2.63 & 0.35 & 1.26 & 0.71 & 0.04 & 1.44 & 0.18 & 27 \\
\hline & 3.17 & 0.11 & 3.24 & 0.33 & 0.98 & 0.54 & 0.04 & 1.48 & 0.10 & 34 \\
\hline & 3.11 & 0.10 & 2.93 & 0.33 & 1.06 & 0.62 & 0.04 & 1.41 & 0.09 & 24 \\
\hline \multirow[t]{3}{*}{ V4 } & 8.42 & 2.26 & 9.34 & 1.72 & 0.90 & 0.96 & 0.08 & 1.68 & 0.11 & 19 \\
\hline & 6.56 & 1.76 & 7.18 & 1.34 & 0.91 & 0.80 & 0.06 & 1.59 & 0.04 & 19 \\
\hline & 4.86 & 1.31 & 6.33 & 0.99 & 0.77 & 0.88 & 0.04 & 1.65 & 0.11 & 27 \\
\hline \multirow[t]{3}{*}{ V3 } & 4.40 & 0.22 & 2.16 & 0.36 & 2.04 & 0.57 & 0.10 & 2.19 & 0.63 & 15 \\
\hline & 4.86 & 0.24 & 2.55 & 0.40 & 1.91 & 0.35 & 0.11 & 2.28 & 0.29 & 14 \\
\hline & 4.63 & 0.23 & 2.35 & 0.38 & 1.97 & 0.46 & 0.11 & 2.36 & 0.69 & 22 \\
\hline \multirow[t]{3}{*}{ V1 } & 3.47 & 0.34 & 3.09 & 0.49 & 1.13 & 0.52 & 0.01 & 1.64 & 0.24 & 33 \\
\hline & 2.86 & 0.28 & 4.09 & 0.40 & 0.70 & 0.54 & 0.00 & 1.67 & 0.21 & 34 \\
\hline & 3.17 & 0.31 & 3.59 & 0.44 & 0.88 & 0.53 & 0.01 & 1.70 & 0.07 & 30 \\
\hline \multirow[t]{3}{*}{ V2 } & 8.30 & 1.48 & 4.71 & 1.25 & 1.76 & 1.03 & 0.23 & 8.72 & 0.64 & 20 \\
\hline & 11.89 & 2.11 & 3.47 & 1.79 & 3.42 & 0.58 & 0.33 & 8.87 & 0.51 & 12 \\
\hline & 10.09 & 1.80 & 4.09 & 1.52 & 2.47 & 0.81 & 0.28 & 8.98 & 0.19 & 18 \\
\hline \multirow[t]{3}{*}{ V6 } & 4.40 & 0.62 & 2.70 & 0.64 & 1.63 & 1.58 & 0.12 & 1.79 & 0.61 & 18 \\
\hline & 3.86 & 0.54 & 3.17 & 0.56 & 1.22 & 0.91 & 0.10 & 1.89 & 0.05 & 24 \\
\hline & 3.32 & 0.46 & 3.63 & 0.49 & 0.91 & 1.24 & 0.09 & 1.87 & 0.07 & 25 \\
\hline \multirow[t]{3}{*}{ V7 } & 11.20 & 1.29 & 2.70 & 0.88 & 4.14 & 0.68 & 0.24 & 1.55 & 0.61 & 32 \\
\hline & 8.88 & 1.02 & 3.17 & 0.70 & 2.80 & 0.44 & 0.19 & 1.35 & 0.06 & 28 \\
\hline & 10.04 & 1.16 & 2.93 & 0.79 & 3.42 & 0.56 & 0.21 & 1.31 & 0.07 & 24 \\
\hline \multirow[t]{3}{*}{ VIERA } & 3.17 & 0.60 & 2.78 & 0.39 & 1.14 & 0.23 & 0.08 & 5.06 & 0.31 & 29 \\
\hline & 4.63 & 0.87 & 3.55 & 0.56 & 1.30 & 0.40 & 0.12 & 3.02 & 0.45 & 30 \\
\hline & 3.90 & 0.73 & 3.17 & 0.48 & 1.23 & 0.32 & 0.10 & 3.43 & 0.93 & 29 \\
\hline \multirow[t]{3}{*}{ V10 } & 5.95 & 0.80 & 5.02 & 0.83 & 1.18 & 0.60 & 0.06 & 3.45 & 0.14 & 12 \\
\hline & 7.80 & 1.05 & 3.78 & 1.09 & 2.06 & 0.73 & 0.07 & 4.78 & 0.13 & 21 \\
\hline & 6.87 & 0.93 & 4.40 & 0.96 & 1.56 & 0.66 & 0.07 & 3.97 & 0.55 & 16 \\
\hline
\end{tabular}




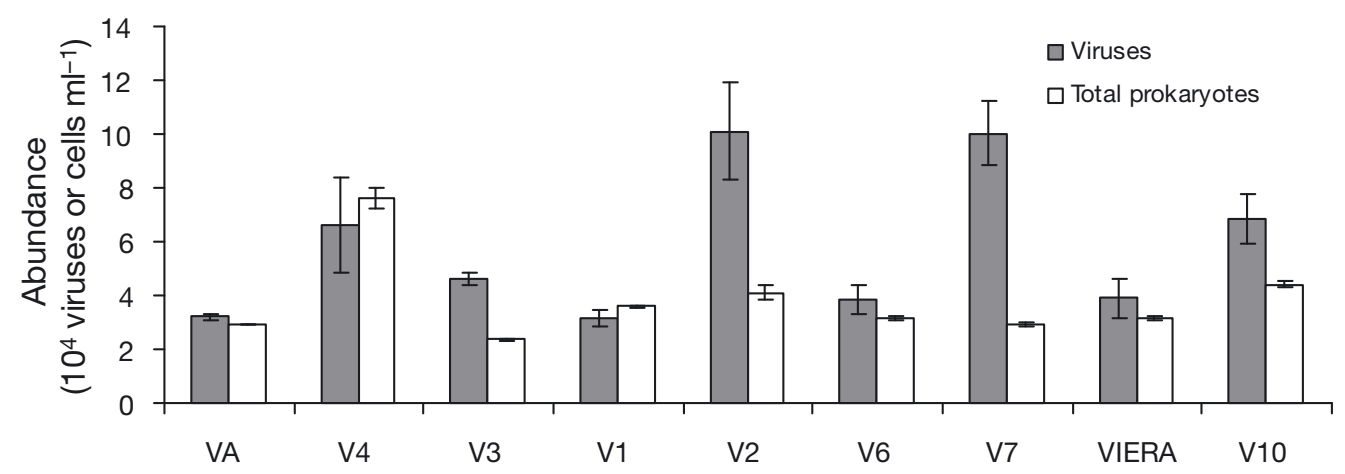

Fig. 2. Spatial patterns of viral and prokaryotic abundances (visualized by SYBR Gold staining) at $1500 \mathrm{~m}$ depth in the Atlantic Ocean (Stn VA) and in the Mediterranean Sea (Stns V4 to V10). Means of 3 independent samples \pm SD

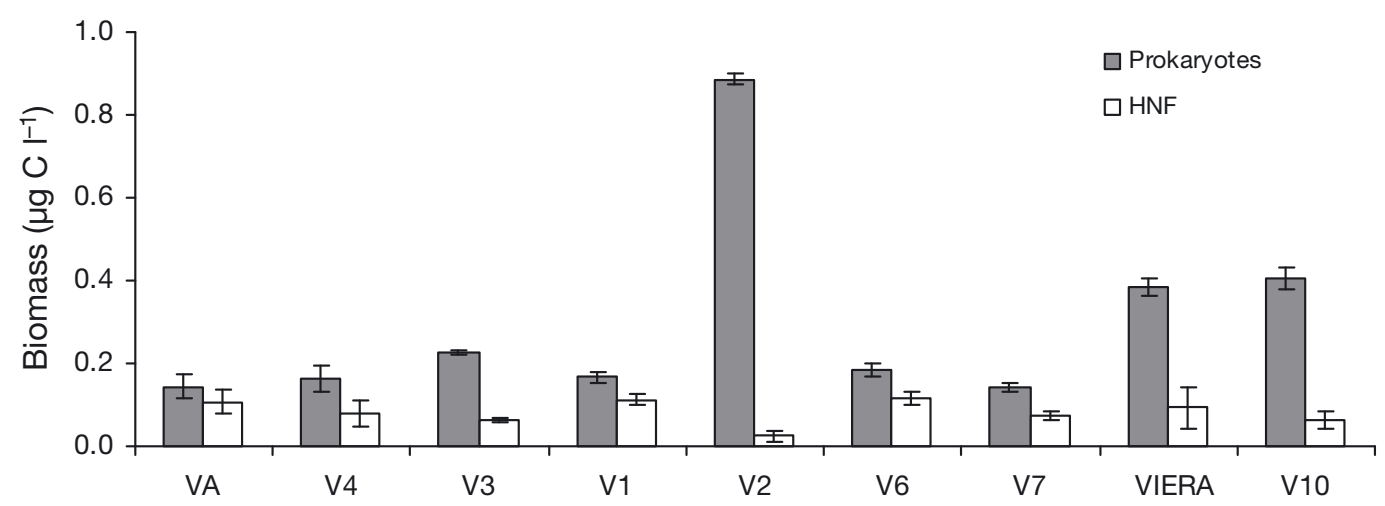

Fig. 3. Spatial patterns of prokaryotic (visualized by DAPI staining) and nanoflagellate (HNF) biomass at $1500 \mathrm{~m}$ depth in the Atlantic Ocean (Stn VA) and in the Mediterranean Sea (Stns V4 to V10). Means of 3 independent samples \pm SD

sured in the eastern basin (on average, $6.13 \pm 2.9 \mathrm{vs}$. $6.17 \pm 2.8 \times 10^{4}$ viruse $\mathrm{ml}^{-1}$ and $4.4 \pm 2.2$ vs. $3.4 \pm 0.7 \times$ $10^{4} \mathrm{HP} \mathrm{ml}^{-1}$ [SYBR Gold], respectively; $\left.\mathrm{p}>0.05\right)$. Viral and HP abundances in the Atlantic Ocean $(3.2 \pm 0.19$ $\times 10^{4}$ viruses $\mathrm{ml}^{-1}$ and $2.93 \pm 0.31 \times 10^{4} \mathrm{HP} \mathrm{ml}{ }^{-1}$, respectively) were generally significantly lower than values reported in the Mediterranean Sea at equal depths ( $p<0.001$ ). HP counts obtained using the 2 stainings (SYBR Gold vs. DAPI) were not significantly different (ANOVA; Table 2). HP biomass varied from $0.14 \pm 0.01 \mu \mathrm{g} \mathrm{C} \mathrm{l}^{-1}$ at Stn VA (Atlantic) and the eastern V7 to a maximum of $0.89 \pm 0.04 \mu \mathrm{C}^{-1}$ at Stn V2 (Fig. 3).

\section{HNF abundance and biomass}

HNF abundance ranged from 12 to 34 cells ml $\mathrm{m}^{-1}$ and HNF biomass ranged from $0.02 \pm 0.01$ to $0.12 \pm 0.02 \mu \mathrm{g}$ $\mathrm{C}^{-1}$ (Table 2, Fig. 3). The highest abundance of grazers was detected at Stns VA and V6. HNF abundances did not differ significantly among stations (ANOVA), and on average, values observed in the western sector $\left(0.082 \pm 0.02 \mu \mathrm{g} \mathrm{C}^{-1}\right)$ corresponded to those of the eastern basin $\left(0.085 \pm 0.02 \mu \mathrm{g} \mathrm{C}^{-1}\right)$.

Small size HNF $(<3 \mu \mathrm{m})$ always numerically dominated the bacterivorous assemblage. Larger organisms (5 to $10 \mu \mathrm{m}$ ) showed lower abundances, but dominated total HNF biomass at all stations.

\section{Microzooplankton variables}

MCZ was mostly constituted by aloricate and loricate (tintinnids) ciliates. Only at some stations were heterotrophic dinoflagellates more abundant, whereas micrometazoans and other protozoans were always very scarce across the studied area (Table 3A, Fig. 4). A total of 26 tintinnid species and 2 genera were identified; the most abundant was Rhabdonella spiralis. Abundances of total MCZ clearly decreased from the western (average: $34.38 \pm 31.9$ ind. $\mathrm{l}^{-1}$ ) to the eastern (average: $11.38 \pm 6.7$ ind $\mathrm{l}^{-1}$ ) basin (Table 3A). Highest abundances were encountered at Stn V2 (78 ind. $\mathrm{l}^{-1}$ ), followed by Stn V3 (34.5 ind. $\mathrm{l}^{-1}$ ), whereas in the eastern sector MCZ abundance was uniformly low, 
with the lowest value at Stn V7 $\left(1.5\right.$ ind. $\left.\mathrm{l}^{-1}\right)$. Aloricate ciliate abundance was homogenous across the entire Mediterranean basin (average: $6.72 \pm 4.58$ ind. $\mathrm{l}^{-1}$ ), except at Stn V1, where ciliate abundance was 14 ind. $\mathrm{l}^{-1}$. MCZ biomass (Table 3B) was generally very low (average: $0.13 \pm 0.8 \mu \mathrm{g} \mathrm{C} \mathrm{l}^{-1}$ ) with the relevant exception of
Stn V2 $\left(2.06 \mu \mathrm{g} \mathrm{C}^{-1}\right)$. At this station most of the biomass was accounted by hetero-dinoflagellates, while at Stns V6 $\left(1.103 \mu \mathrm{g} \mathrm{Cl}^{-1}\right)$ and V10 $\left(1.073 \mu \mathrm{g} \mathrm{C} \mathrm{l}^{-1}\right)$ mostly represented by protozoans, (e.g. Colodendrida spp.). The lowest biomass values were observed at Stns V4 and V1 with $0.014 \mathrm{\mu g} \mathrm{Cl}^{-1}$.

Table 3. Quantification of taxonomic groups from all stations. (A) Abundances (ind. $\mathrm{l}^{-1}$ ) of each species of tintinnids, total tintinnids, and of the main microzooplankton groups, total ciliates (aloricate ciliates and tintinnids), heterodinoflagellates, micrometa-

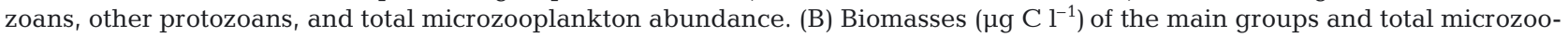
plankton biomass

\begin{tabular}{|c|c|c|c|c|c|c|c|c|c|}
\hline \multirow{2}{*}{ Taxon } & \multicolumn{9}{|c|}{ - Station - } \\
\hline & VA & V4 & V3 & V1 & V2 & V6 & V7 & VIERA & V10 \\
\hline \multicolumn{10}{|l|}{ (A) Abundance (ind. $\mathrm{l}^{-1}$ ) } \\
\hline Aloricate ciliates & 6.5 & 5.5 & 7.5 & 14 & 11 & 1.5 & 1 & 8 & 2 \\
\hline Acanthostomella minutissima & & & 2 & & & & & & \\
\hline Amphorella amphora & & & & & 8 & & & & \\
\hline Amphorella quadrilineata & 0.5 & & & & & & & & \\
\hline Codonella aspera & & & & & & & & 0.5 & \\
\hline Codonella pacifica & & & & & 0.5 & & & & \\
\hline Codonellopsis contracta & & & & 1 & & & & 0.5 & \\
\hline Craterella brevis & & & & & 4.5 & & & & \\
\hline Craterella spp. & & & & & 1 & & & & \\
\hline Craterella urceolata & & & & & 1 & & & 0.5 & \\
\hline Dadayiella ganymedes & & & & & 3.5 & & & & \\
\hline Epiplocylis constricta & & & & & & 0.5 & & 0.5 & 0.5 \\
\hline Epirhabdonella mucronata & & & 0.5 & & & & & & \\
\hline Eutintinnus elegans & & & 0.5 & & & & & & \\
\hline Eutintinnus lusus-undae & & & 2.5 & & 3 & & & & 1 \\
\hline Eutintinnus pinguis & & & 1 & & & & & & \\
\hline Eutintinnus spp. & 1.5 & & & & & & & & \\
\hline Eutintinnus stramenus & & & & & & & & & 0.5 \\
\hline Eutintinnus tubulosus & & 0.5 & & & 4 & & & & \\
\hline Parundella spp. & & & & & & 0.5 & & 0.5 & \\
\hline Proplectella ovata & & & 0.5 & & & 0.5 & & & \\
\hline Protorhabdonella curta & & & 6.5 & & 1 & & & & \\
\hline Rhabdonella spiralis & & & 1 & & 9 & 1.5 & & 1.5 & 0.5 \\
\hline Rhabdonella spp. & & & & & 0.5 & 0.5 & & 0.5 & \\
\hline Salpingella spp. & & & & & 0.5 & & & & \\
\hline Steenstrupiella steenstrupii & 0.5 & & 1.5 & & 4.5 & & & & \\
\hline Stenosemella nivalis & & & 2 & 0.5 & & & & & \\
\hline Tintinnopsis lindeni & & & & & & & & & 0.5 \\
\hline Undella pistillum & & & 0.5 & & & & & & \\
\hline Undella turgida & & & & & & 0.5 & & & \\
\hline Xystonella longicauda & 0.5 & & & & & & & & 0.5 \\
\hline Unidentified tintinnids & 2.5 & 2 & 2 & & & & & & \\
\hline Total tintinnids & 5.5 & 2.5 & 20.5 & 1.5 & 41 & 4 & 0 & 4.5 & 3.5 \\
\hline Total ciliates & 12 & 8 & 28 & 15.5 & 52 & 5.5 & 1 & 12.5 & 5.5 \\
\hline Heterodinoflagellates & 0 & 0 & 4.5 & 0 & 15 & 5 & 0 & 1 & 7.5 \\
\hline Micrometazoans & 0 & 0 & 0 & 0.5 & 7 & 2 & 0.5 & 2.5 & 0.5 \\
\hline Other protozoans & 0 & 0 & 2 & 1 & 4 & 1 & 0 & 0 & 1 \\
\hline Total microzooplankton & 12 & 8 & 34.5 & 17 & 78 & 13.5 & 1.5 & 16 & 14.5 \\
\hline \multicolumn{10}{|l|}{ (B) Biomass ( $\mu \mathrm{g} \mathrm{C}^{-1}$ ) } \\
\hline Aloricate ciliates & 0.001 & 0.004 & 0.010 & 0.003 & 0.006 & 0.000 & 0.000 & 0.002 & 0.005 \\
\hline Tintinnids & 0.079 & 0.010 & 0.061 & 0.001 & 0.333 & 0.013 & 0.000 & 0.049 & 0.030 \\
\hline Total ciliates & 0.080 & 0.014 & 0.071 & 0.004 & 0.339 & 0.013 & 0.000 & 0.051 & 0.035 \\
\hline Heterodinoflagellates & 0.023 & 0.000 & 0.060 & 0.000 & 1.378 & 0.015 & 0.000 & 0.016 & 0.014 \\
\hline Micrometazoans & 0.000 & 0.000 & 0.000 & 0.001 & 0.299 & 0.075 & 0.025 & 0.100 & 0.025 \\
\hline Other protozoans & 0.000 & 0.000 & 0.037 & 0.009 & 0.040 & 1.000 & 0.000 & 0.000 & 1.000 \\
\hline Total microzooplankton & 0.103 & 0.014 & 0.168 & 0.014 & 2.057 & 1.103 & 0.025 & 0.167 & 1.073 \\
\hline
\end{tabular}




\section{Viral production and viral-induced prokaryotic mortality}

Viral production rates ranged from $0.23 \pm 0.08$ to $1.58 \pm 0.12 \times 10^{4}$ viruses $\mathrm{ml}^{-1} \mathrm{~h}^{-1}$ (Table 2, Fig. 5), and displayed significant differences among stations (ANOVA, $\mathrm{p}<0.001$ ). However, no significant differences were observed comparing the average values of the 2 Mediterranean basins $(0.67 \pm 0.21$ vs. $0.69 \pm$ $0.39 \times 10^{4}$ viruses $\mathrm{ml}^{-1} \mathrm{~h}^{-1}$ in the western and eastern

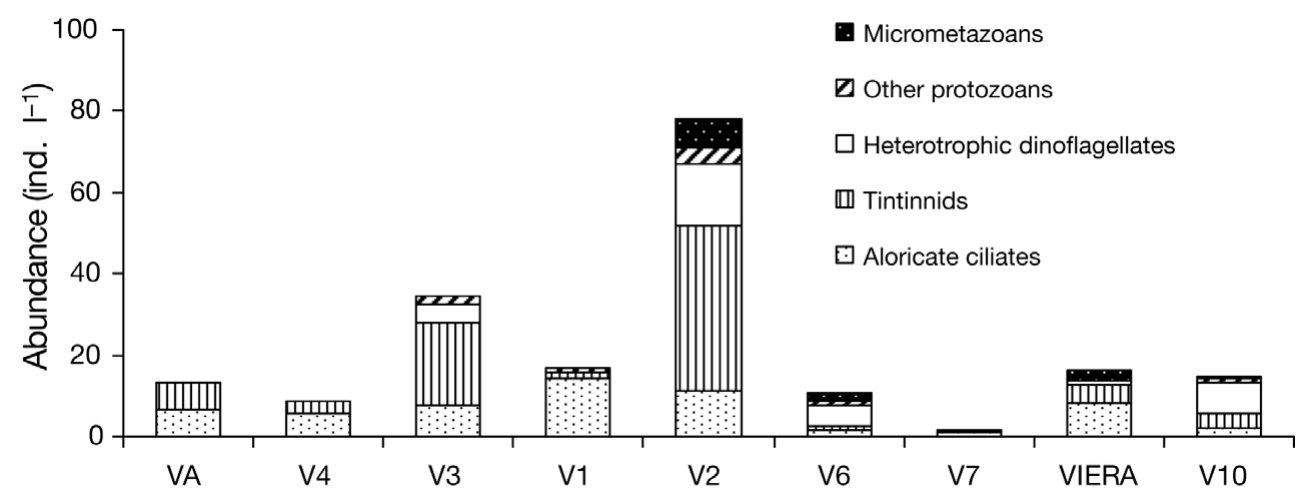

Fig. 4. Microzooplankton main groups. Spatial patterns of their abundances at $1500 \mathrm{~m}$ depth in the Atlantic Ocean (Stn VA) and in the Mediterranean Sea (Stns V4 to V10)

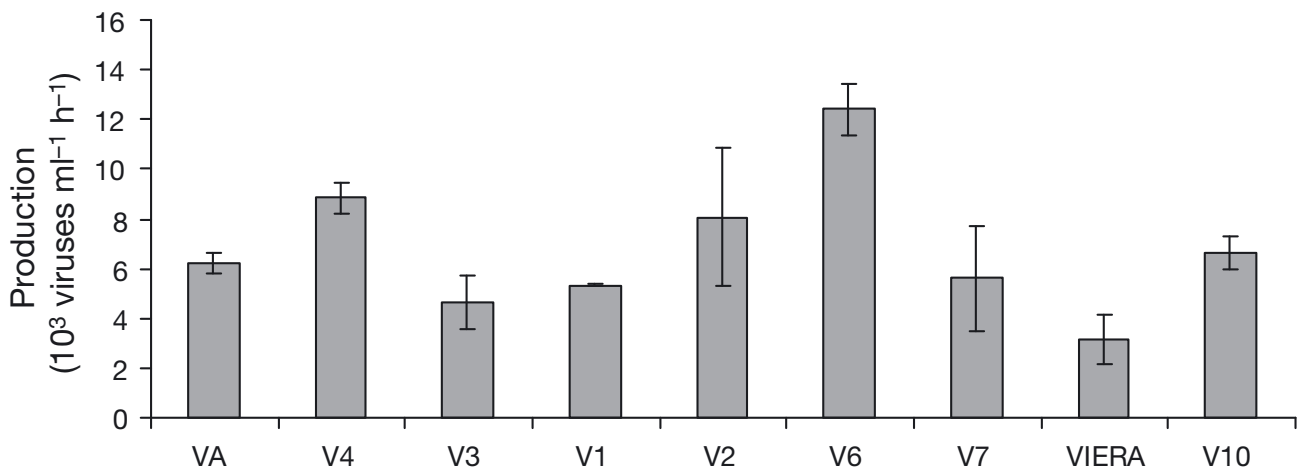

Fig. 5. Viral production. Spatial patterns at $1500 \mathrm{~m}$ depth in the Atlantic Ocean (Stn VA) and in the Mediterranean Sea (Stns V4 to V10). Means of 3 independent samples \pm SD

Table 4. For each station are reported: prokaryotic initial biomass $\left(C_{0}\right)$, SD, average prokaryotic biomass over the dilution experiment time course $\left(C_{\mathrm{m}}\right)$ calculated as the average between $C_{0}$ and $C_{t}$, daily apparent growth rate $(k)$, daily grazing rate $(G)$, coefficient of correlation of the linear regression ( $\mathrm{r}$ ), daily ingestion as $G C_{\mathrm{m}}$, initial prokaryotic cells : killed cells by viral lysis ratio $(s)$, percentage of killed cells by HNF grazing alone (\% HNF) and percentage of killed cells by viral lysis (\% virus) on the initial standing stock

\begin{tabular}{|c|c|c|c|c|c|c|c|c|c|c|}
\hline Stn & $\left(\mu g \mathrm{Cl}^{-1}\right)$ & SD & $\begin{array}{c}C_{\mathrm{m}} \\
\left(\mu \mathrm{C}^{-1}\right)\end{array}$ & $\begin{array}{c}k \\
\left(d^{-1}\right)\end{array}$ & $\begin{array}{c}G \\
\left(\mathrm{~d}^{-1}\right)\end{array}$ & $\mathrm{r}$ & 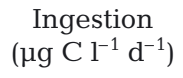 & $\begin{array}{c}S \\
\left(d^{-1}\right)\end{array}$ & $\begin{array}{c}\% \text { HNF } \\
\left(d^{-1}\right)\end{array}$ & $\begin{array}{l}\% \text { virus } \\
\left(\mathrm{d}^{-1}\right)\end{array}$ \\
\hline VA & 0.14 & 0.01 & 0.11 & -0.04 & 0.41 & 0.88 & 0.05 & 6.66 & 0.00 & 15.02 \\
\hline V4 & 0.16 & 0.01 & 0.12 & 1.06 & 1.55 & 0.89 & 0.19 & 12.21 & 91.81 & 8.19 \\
\hline V3 & 0.23 & 0.05 & 0.16 & 4.21 & 4.4 & 0.88 & 0.70 & 7.20 & 86.11 & 13.89 \\
\hline V1 & 0.17 & 0.02 & 0.18 & 4.64 & 3.79 & 0.87 & 0.70 & 9.52 & 71.22 & 10.50 \\
\hline V2 & 0.89 & 0.04 & 0.53 & 5.08 & 6.33 & 0.98 & 3.38 & 7.18 & 86.07 & 13.93 \\
\hline V6 & 0.18 & 0.03 & 0.52 & 2.94 & 1.15 & 0.72 & 0.59 & 3.61 & 11.54 & 27.69 \\
\hline V7 & 0.14 & 0.01 & 0.65 & 4.5 & 1.93 & 0.83 & 1.26 & 7.43 & 30.26 & 13.47 \\
\hline VIERA & 0.38 & 0.11 & 2.30 & 4 & 1.13 & 0.58 & 2.60 & 14.22 & 20.85 & 7.03 \\
\hline V10 & 0.41 & 0.06 & 1.07 & 2.72 & 1.41 & 0.88 & 1.51 & 9.41 & 47.71 & 10.63 \\
\hline
\end{tabular}



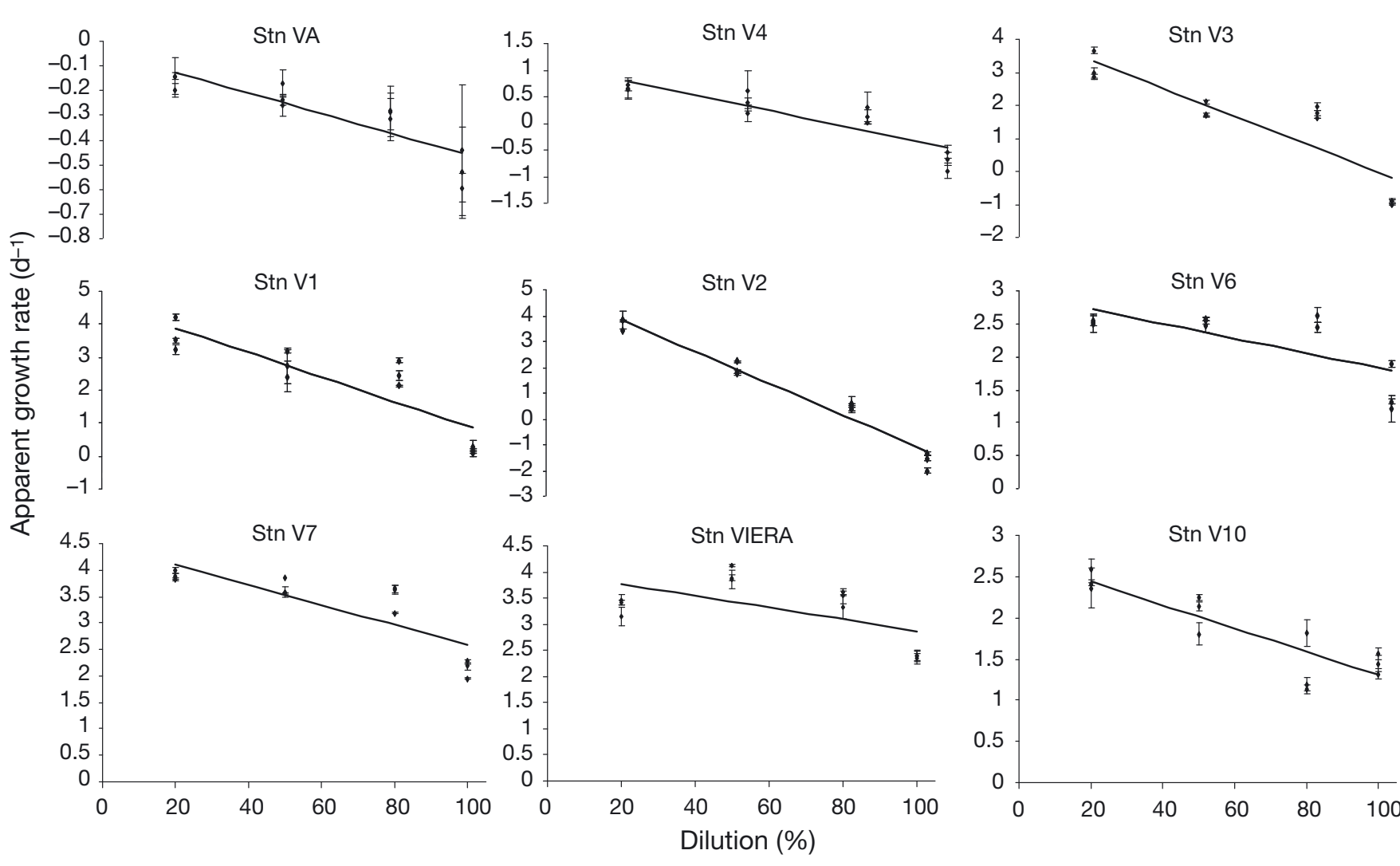

Fig. 6. Apparent growth rates of prokaryotes and the degree of dilution of $10 \mu \mathrm{m}$ filtered sea water with $0.1 \mu \mathrm{m}$ filtered sea water in the 9 experiments. Means of 3 samples \pm SD for each dilution step and their linear fits. Statistical parameters are reported in Table 4

Mediterranean, respectively; $t$-test not significant). In the Atlantic Ocean viral production did fall within the range of values reported for the bathypelagic waters of the Mediterranean Sea, with values very close to the average values of both basins (Stn VA: $0.62 \pm 0.08 \times$ $10^{4}$ viruses $\mathrm{ml}^{-1} \mathrm{~h}^{-1}$ ). Viral induced prokaryotic mortality was always very high, ranging from $7 \%$ (Stn VIERA) to $27.7 \%$ of HP abundance, on a daily basis.

\section{Grazing rates of $\mathrm{HNF}$ on $\mathrm{HP}$}

The dilution efficiency was checked for all experiments conducted: HP abundance decreased as expected following the dilution factor. The results of the dilution experiments are summarized in Table 4. All regressions were highly significant $(\mathrm{p}<0.001$; Table 4$)$, with the exception of Stn VIERA $(p<0.05)$. In each incubation experiment, the relationship between the apparent HP growth rate and the dilution gradient was linear (Fig. 6). In 4 out of the 5 eastern stations, HP apparent growth constants $(k)$ were higher than grazing constants $(G)$ (Table 4). Therefore, in the eastern basin, on average, HP potential production (as calculated using the apparent growth constant $k$ ) was higher than mortality. The opposite was observed in 3 Stns of the western basin (V4, V3, V2), where HNF grazing pressure was higher than HP growth rates, thus able to control prey abundance. In the Atlantic bathypelagic waters, we registered the only negative value of apparent growth constant. Ingestion rates ranged from 0.06 to $5.93 \mu \mathrm{g} \mathrm{Cl}^{-1} \mathrm{~d}^{-1}$ (Table 4), equivalent to between 28 and $100 \%$ mortality of HP per day.

\section{DISCUSSION}

The current opinion is that bathypelagic ecosystems depend on the POM supply from the overlaying water column (i.e. bottom-up controlled). Recently, however, Nagata et al. (2010) indicated that assessment of the rates at which prokaryotes are consumed by HNF and lysed by viruses is an essential future research direction in the bathypelagic realm. Furthermore, based on a large dataset on HNF and HP abundances, Aristegui et al. (2009) suggested that in the dark ocean HNFs could 
be as important as predators of HP as in the epipelagic zone. They also argued (op. cit.) that the abundance of HNF in this environment is likely constrained by the available food in the form of HP biomass, and possibly, given the small number of ciliates, no top-down control of HNF abundance exists in the deep ocean. Viral abundances in epi-, meso- and bathypelagic waters of the Mediterranean Sea are high when compared with literature data available from open oceans (Wommack \& Colwell 2000) and a clear increasing pattern of viral abundance moving from the Atlantic to the eastern Mediterranean waters has been already documented (Magagnini et al. 2007). The high viral abundance is particularly evident for benthopelagic waters, where the ratio of viral to prokaryotic abundance can be higher than values reported in epipelagic waters (cf. Magagnini et al. 2007). According to previous studies conducted in deep-sea sediments it is possible that viruses are important mortality agents for prokaryotes in bathypelagic waters (Danovaro et al. 2008).

The main aim of our study was to disentangle the effect of viruses and HNF on HP mortality rates in bathypelagic systems spanning over a wide geographical range from the Atlantic Ocean to the eastern Mediterranean Sea. Here we report the results of the first sets of independent experiments performed in the bathypelagic waters of the Mediterranean Sea (and Atlantic) to assess HNF and virus induced HP mortality. Results obtained in our study indicate that both viruses and HNFs caused significant HP biomass losses, on average 13.4 and $49.5 \%$ of the HP initial standing stock, respectively. Our results indeed suggest that major shifts in the top-down control can be observed by comparing different biogeographic regions at bathyal depths. We found that in certain deep-water samples, such as in the Atlantic sector, the viral shunt accounted for almost the entire HP mortality, while in other areas, such as the western Mediterranean, HNF grazing apparently prevailed over the viral shunt. In the highly oligotrophic eastern Mediterranean basin, the viral shunt was more important than in the western Mediterranean and, on average, balanced the effects of HNF grazing.

When data from dilution experiments of HP mortality, which is assumed to be due solely to HNF grazing, are compared with the mortality due to viral infections, it is apparent that a larger fraction (on average ca. $49 \%$ ) of the HP abundance is removed by grazing on daily basis. On the basis of independent experiments conducted on replicated deep-water samples, we conclude that if viral and HNF mortality rates are summed, they would cause a mortality of ca. $63 \%$ of the HP abundance on daily basis. However, HP mortality due to viral infection and HNF grazing cannot be simply summed up. In fact, in the controls for the grazing experiments (carried out by dilution) we removed all of the potential grazers larger than HNF, but we did not remove HP and viruses (Evans et al. 2003, Kimmance et al. 2007). Similar conclusions were drawn from a recent study conducted by Taira et al. (2009). In the Taira et al. (2009) study, a dilution approach was used that is similar to the one we used, but the effect on HP due to viruses was removed by selective tangential flow filtration of the water used for dilution experiments. This indicates that the viral infections occur simultaneously with the grazing of HNF over HP. Therefore, using an approach similar to the one recently described by Taira et al. (2009), the actual effect of HNF on HP mortality can be calculated only by calculating the difference between the estimates carried out using the dilution approach of Landry \& Hassett (1982) and the mortality rates caused by viral infections of HP.

On the light of what reported above, we suggest that the role of grazing and the effect of HNF on HP has been previously overestimated due to the fact that the dilution experiments included also viral lysis, and that this effect was not considered.

Consequently, the equation to estimate HP mortality by HNF grazing should be modified from:

to:

$$
\begin{gathered}
C_{t}=C_{0} \mathrm{e}^{(k-G) t} \\
C_{t}=C_{0} \mathrm{e}^{[(k-s)-G] t}
\end{gathered}
$$

where $k$ is the apparent growth constant as estimated by standard dilution experiments and $s$ is the ratio between total initial HP abundances and killed cells by viral lysis per day estimated by viral production dilution experiments.

The dilution method requires several assumptions and the fulfilment of specific conditions. These problems are exacerbated in deep-water samples, where the potential food limitation and effect of decompression might further complicate the experimental approach. Moreover, we have no exact information on the potential effect of the shear stress during filtration over HP metabolism. However, all of these potentially stressful conditions had a very limited effect on our experimental bathypelagic samples as results reported here indicate that both HP and HNF were active and dynamic, being able to grow over the time-course experiments. Moreover, additional experiments conducted using high-pressure bottles (to maintain the in situ pressure) and Niskin bottles for the determinations of viral production at bathyal depths by means of ${ }^{3} \mathrm{H}$ thymidine incorporation revealed a perfect match with the values obtained by the dilution technique, thus indicating that the effect of decompression was negligible (Danovaro et al. 2008).

Dilution experiments were performed on water samples collected at $1500 \mathrm{~m}$ depth and $10 \mu \mathrm{m}$ prefiltered in 
order to remove all large predators. Consequently our data refer only to cells $<10 \mu \mathrm{m}$. HNF abundances (size:

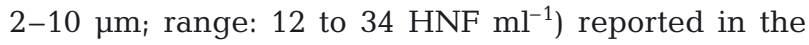
present study are within the range of those previously reported from the deep waters of the western Mediterranean (Tanaka \& Rassoulzadegan 2002, Nagata et al. 2010). The pre-filtration and consequent removal of MCZ could cause higher growth rates of $\mathrm{HNF}$, which can be preyed by MCZ (Vaqué et al. 1994). Therefore, one of the intrinsic limits of our approach is that the estimates reported here should be considered as the highest potential grazing rates of HNF on HP. At the same time it is also known that MCZ can directly prey upon HP (Fonda Umani \& Beran 2003), thus contributing to HP mortality. HNF abundance was always very low, the most diluted samples (i.e. $80 \%$ of filtered sea water) contained 2 to $7 \mathrm{HNFs} \mathrm{ml}^{-1}$ that could have resulted in the virtual absence of HNF predation on HP. Therefore extrapolated apparent growth rate $(k)$ to $100 \%$ filtered sea water obtained by the model equation could be unrealistic high. Unfortunately, there are no literature data on dilution experiments conducted in bathypelagic water for a comparison. Comparison with prokaryotic carbon production obtained by incorporations of labelled leucine or thymidine are uncorrected, because they are assessed over short time incubations in unenriched samples, where however viral lysis is still going on. Nonetheless our growth rates are comparable with data reported for the deep Mediterranean Sea (e.g. Tamburini et al. 2009) or elsewhere (Nagata et al. 2010).

In the present study, at $1500 \mathrm{~m}$ we found relatively high viral production rates, with values comparable to those previously reported for coastal systems (Corinaldesi et al. 2003). A high microbial metabolism is generally expected to drive high levels of viral infection and a consequent significant effect of viral lysis over the HP assemblage. This phenomenon is apparently enhanced in the deep Mediterranean where the high deep-water temperatures (exceeding those reported for the deep Atlantic by $\sim 10^{\circ} \mathrm{C}$; Magagnini et al. 2007) might increase microbial metabolism. However, in the present study, the effect of temperature was not evident, as values of viral production (VP) reported in Atlantic waters are similar to those reported in the deep Mediterranean Sea.

The high VP values are responsible for an important HP mortality. To estimate prokaryotic mortality from VP we used a conservative value of the burst size (BS), but we are aware that this value can vary among stations. However, previous studies revealed a very narrow range of variation for the BS in Mediterranean deep-waters (cf. Parada et al. 2007). In the present study we found that up to $1 / 3$ (on average $13 \%$ ) of the total HP abundance was apparently lysed by viral infection. We observed neither specific spatial trends across the Mediterranean basin nor differences when comparing the Mediterranean and the Atlantic waters of the same depths. These results suggest that, as recently reported for coastal systems (Taira et al. 2009), viral infection can play a consistent and important role in the HP dynamics in bathypelagic water, also across different environmental conditions.

In bathypelagic waters of the Mediterranean Sea, MCZ abundance and biomass were very low. This is in good agreement with the general rule of a more consistent decrease with depth of the abundance and biomass of higher trophic level plankton (Aristegui et al. 2009). Results reported here are also consistent with those previously reported in the deep Mediterranean, particularly when the comparison is based on the abundance of ciliates (aloricate and loricate [tintinnids]; range 1 to 52 ind. $\mathrm{l}^{-1}$; Tanaka \& Rassoulzadegan 2002) although it is well known that formaldehyde is a poor preservative for naked ciliates. In the present study we also investigated heterotrophic dinoflagellates (relatively abundant only at Stn V2), other protozoans (e.g. radiolarians) and micrometazoans (mainly copepod nauplii). The highest biomass was reported at Stn V2 because of a single specimen of Noctiluca scintillans, which for its size contributed ca. $50 \%$ of total MCZ biomass. However, given the very low abundance of $\mathrm{MCZ}$, it can be expected that grazing pressure on HNF and HP was extremely limited. Using coefficients calculated in previous studies (Fonda Umani et al. 2005b) it can be estimated a HNF mortality caused by MCZ grazing equivalent to between 0.0014 and $0.46 \mu \mathrm{g} \mathrm{Cl}^{-1} \mathrm{~d}^{-1}$ (at Stn V2). For this reason the MCZ component was considered negligible for HP dynamics, as suggested by Aristegui et al. (2009), and all experiments were focused exclusively on the relative importance of HNF grazing and viral infections of prokaryotes.

We are aware that the dilution approach must be used with extreme caution, especially in deep-water samples, where besides the assumptions made, it can be also influenced by the experimental conditions which can alter both HP metabolism and HNF grazing rates (Tamburini et al. 2003). However, we consider our results useful for comparative purposes. Results based on simultaneous analysis of the relative importance of viruses and HNF on HP mortality can provide new insight on the ecological conditions controlling microbial dynamics in deep water. Despite this, it is evident that estimates based on direct measurements require further validation and accurate measurements of doubling time and in situ metabolism in order to understand the extent by which HNF and viruses can control HP dynamics and to elucidate which factors promote the importance of grazing vs. the viral shunt in bathypelagic waters. 
Acknowledgements. This work was carried out within the frame of the programmes VECTOR and OBAMA financially supported by the Italian Government (Ministry for University and Scientific Research). We are grateful to 3 anonymous reviewers whose suggestions strongly improved the manuscript.

\section{LITERATURE CITED}

Agis M, Granda A, Dolan JR (2006) A cautionary note: examples of possible microbial community dynamics in dilution grazing experiments. J Exp Mar Biol Ecol 34:176-183

Aristegui J, Gasol JM, Duarte CM, Herndl GJ (2009) Microbial oceanography of the dark ocean's pelagic realm. Limnol Oceanogr 54:1501-1529

Bamstedt U, Gifford D, Atkinson A, Irigoien X, Roman M (2000) Feeding. In: Harris R, Wiebe P, Lanz J, Skjoldal HR (eds) ICES zooplankton methodology manual. Academic Press, San Diego, CA, p 297-399

Beers JR, Stewart GL (1970) Part IV. Numerical abundance and estimated biomass of microzooplankton. In: Strickland JDH (ed) The ecology of the plankton off La Jolla, California, in the period April through September 1967. University of California Press, Berkeley, CA, p 67-87

Berninger UG, Wickham SA (2005) Response of the microbial food web to manipulation of nutrients and grazers in the oligotrophic Gulf of Aqaba and northern Red Sea. Mar Biol 147:1017-1032

Buck KR, Garrison DL, Hopkins TL (1992) Abundance and distribution of tintinnid ciliates in an ice edge zone during the austral autumn. Antarct Sci 4:3-8

Caron DA (2001) Protistan herbivory and bacterivory. In: Paul JH (ed) Marine microbiology. Methods in microbiology, Vol 30. Academic Press, San Diego, CA, p 289-315

Caron DA, Lim EL, Miceli G, Waterbury JB, Valois FW (1991) Grazing and utilization of chroococcoid cyanobacteria and heterotrophic bacteria by protozoa in laboratory cultures and a coastal plankton community. Mar Ecol Prog Ser 76: 205-217

Caron DA, Dam HG, Kremer P, Lessard EJ and others (1995) The contribution of microrganisms to particulate carbon and nitrogen in surface waters of the Sargasso Sea near Bermuda. Deep-Sea Res I 46:943-972

Chen F, Lu JR, Binder BJ, Liu YC, Hodson RE (2001) Application of digital image analysis and flow cytometry to enumerate marine viruses stained with SYBR gold. Appl Environ Microbiol 67:539-545

Corinaldesi C, Crevatin E, Del Negro P, Marini M, Russo A, Fonda Umani S, Danovaro R (2003) Large-scale spatial distribution of virioplankton in the Adriatic Sea. Appl Environ Microbiol 69:2664-2673

- Danovaro R, Dell'Anno A, Trucco A, Vannucci S (2001) Determination of virus abundance in marine sediments. Appl Environ Microbiol 67:1384-1387

> Danovaro R, Dell'Anno A, Corinaldesi C, Magagnini M, Noble R, Tamburini C, Weinbauer M (2008) Major viral impact on the functioning of benthic deep-sea ecosystems. Nature 454:1084-1087

> Dolan JR, McKeon K (2005) The reliability of grazing rate estimates from dilution experiments: Have we over-estimated rates of organic carbon consumption by microzooplankton? Ocean Sci 1:1-7

$>$ Dolan JR, Ritchie ME, Ras J (2007) The 'neutral' community structure of planktonic herbivores, tintinnid ciliates of the microzooplankton, across the SE Tropical Pacific Ocean. Biogeosciences Discuss 4:561-593
Evans C, Archer SD, Jaquet S, Wilson WH (2003) Direct estimates of the contribution of viral lysis and microzooplankton grazing to the decline of a Micromonas spp. population. Aquat Microb Ecol 30:207-219

- Fonda Umani S, Beran A (2003) Seasonal variations in the dynamics of microbial plankton communities: first estimates from experiments in the Gulf of Trieste, Northern Adriatic Sea. Mar Ecol Prog Ser 247:1-16

Fonda Umani S, Monti M, Bergamasco A, Cabrini M, De Vittor C, Del Negro P (2005a) Plankton community structure and dynamics versus physical structure from Terra Nova Bay to Ross Ice Shelf (Antarctica). J Mar Syst 55:31-46

> Fonda Umani S, Tirelli V, Beran A, Guardiani B (2005b) Relationships between microzooplankton and mesozooplankton: competition vs predation on natural assemblages in the Gulf of Trieste (northern Adriatic Sea). J Plankton Res 27:973-986

Gasol JM, Vaqué D (1993) Lack of coupling between heterotrophic nanoflagellates and bacteria: a general phenomenon across aquatic systems? Limnol Oceanogr 38:657-665

Helton RR, Liu L, Wommack KE (2006) Assessment of factors influencing direct enumeration of viruses within estuarine sediments. Appl Environ Microbiol 72:4767-4774

Herndl GJ, Agogué H, Baltar F, Reinthaler T, Sintes E, Varela MM (2008) Regulation of aquatic microbial processes: the 'microbial loop' of the sunlit surface waters and the dark ocean dissected. Aquat Microb Ecol 53:59-68

Jörgensen E (1924) Mediterranean Tintinnidae. Report on the Danish oceanographical expedition 1908-1910 to the Mediterranean and adjacent seas. II (Biology), J.3. Andr Fred Horst \& Son, Copenhagen

Jürgens K, Massana R (2008) Protistan grazing on marine bacterioplankton. In: Kirchman DL (ed) Microbial ecology of the ocean, 2nd edn. Wiley-Liss, Hoboken, NJ, p 383-441

- Kimmance SA, Wilson WH, Archer SD (2007) Modified dilution technique to estimate viral versus grazing mortality of phytoplankton: limitations associated with method sensitivity in natural waters. Aquat Microb Ecol 49:207-222

> Kiørboe T, Møhlenberg F, Hamburger K (1985) Bioenergetics of the planktonic copepod Acartia tonsa: relation between feeding, egg production and respiration, and composition of specific dynamic action. Mar Ecol Prog Ser 26:85-97

Kofoid CA, Campbell S (1929) A conspectus of the marine and fresh-water ciliate belonging to the sub order Tintinnoinea, with description of new species principally from the Agassiz expedition to the eastern Tropical Pacific 1904-1905. Univ Calif Publ Zool 34:1-403

Landry MR, Hassett RP (1982) Estimating the grazing impact of marine microzooplankton. Mar Biol 67:283-288

Lessard EJ (1991) The trophic role of heterotrophic dinoflagellates in diverse marine environments. Mar Microb Food Webs 5:49-58

Lessard EJ, Murrell MC (1998) Microzooplankton herbivory and phytoplankton growth in the northwestern Sargasso Sea. Aquat Microb Ecol 16:173-188

> Magagnini M, Corinaldesi C, Monticelli LS, De Domenico E, Danovaro R (2007) Viral abundance and distribution in mesopelagic and bathypelagic waters of the Mediterranean Sea. Deep-Sea Res I 54:1209-1220

Marshall SM (1969) Protozoa order Tintinnida. Cons Int Explor Mer, Fiches d'Identification du Zooplankton. Fiches 117-127

> Mei ML, Danovaro R (2004) Virus production and life strategies in aquatic sediments. Limnol Oceanogr 49:459-470

> Murrell MC, Hollibaugh JT (1998) Microzooplankton grazing in northern San Francisco Bay measured by the dilution 
method. Aquat Microb Ecol 15:53-65

Nagata T, Tamburini C, Arístegui J, Baltar F and others (2010) Emerging concepts on microbial processes in the bathypelagic ocean-ecology, biogeochemistry and genomics. Deep-Sea Res II 57:1519-1536

Pace ML, McManus GB, Findlay SEG (1990) Planktonic community structure determines the fate of bacterial production in a temperate lake. Limnol Oceanogr 35:795-808

Pakhomov EA, Perissinotto R (1997) Mesozooplankton community structure and grazing impact in the region of the Subtropical Convergence south of Africa. J Plankton Res 19:675-691

Parada V, Sintes E, van Aken HM, Weinbauer MG, Herndl GJ (2007) Viral abundance, decay, and diversity in the mesoand bathypelagic waters of the North Atlantic. Appl Environ Microbiol 73:4429-4438

Patel A, Noble RT, Steele JA, Schwalbach MS, Hewson I, Fuhrman JA (2007) Virus and prokaryote enumeration from planktonic aquatic environments by epifluorescence microscopy with SYBR Green I. Nat Protoc 2:269-276

> Pedros-Alio C, Calderon-Paz JI, Gasol JM (2000) Comparative analysis show that bacterivory, not viral lysis, controls the abundance of heterotrophic prokaryotic plankton. FEMS Microbiol Ecol 32:157-165

> Pernthaler J (2005) Predation on prokaryotes in the water column and its ecological implications. Nat Rev Microbiol 3: 537-546

Porter KG, Feig YG (1980) The use of DAPI for identifying and counting aquatic microflora. Limnol Oceanogr 25:943-948

Putt M, Stoecker DK (1989) An experimentally determined carbon: volume ratio for marine 'oligotrichous' ciliates from estuarine and coastal waters. Limnol Oceanogr 34: 1097-1103

Rampi L, Zattera A (1982) Chiave per la determinazione dei Tintinnidi mediterranei. Comitato nazionale per la ricerca e per lo sviluppo dell'energia nucleare e delle energie alternative, Rome

Reinthaler T, van Aken $\mathrm{H}$, Veth $\mathrm{C}$, Arìstegui $\mathrm{J}$ and others (2006) Prokaryotic respiration and production in the mesoand bathypelagic realm of the eastern and western North Atlantic basin. Limnol Oceanogr 51:1262-1273

Sherr BF, Sherr EB, Fallon RD (1987) Use of monodispersed, fluorescently labelled bacteria to estimate in situ protozoan bacterivory. Appl Environ Microbiol 53:958-965

Strom SL (2000) Bacterivory: interactions between bacteria and their grazers. In: Kirchman DL (ed) Microbial ecology of the ocean. Wiley-Liss, Hoboken, NJ, p 351-386

> Taira Y, Uchimiya M, Kudo I (2009) Simultaneous estimation of viral lysis and protozoan grazing on bacterial mortality using a modified virus-dilution method. Mar Ecol Prog Ser 379:23-32

Tamburini C, Garcin J, Bianchi A (2003) Role of deep-sea bacteria in organic matter mineralization and adaptation to hydrostatic pressure conditions in the NW Mediterranean Sea. Aquat Microb Ecol 32:209-218

Tamburini C, Garel M, Al Ali B, Mérigot B, Kriwy P, Charrière

Editorial responsibility: Laura Airoldi,

Ravenna, Italy
B, Budillon G (2009) Distribution and activity of Bacteria and Archaea in the different water masses of the Tyrrhenian Sea. Deep-Sea Res II 56:700-712

> Tanaka T, Rassoulzadegan F (2002) Full-depth profile $(0-2000 \mathrm{~m})$ of bacteria, heterotrophic nanoflagellates and ciliates in the NW Mediterranean Sea: Vertical partitioning of microbial trophic structures. Deep-Sea Res II 49: 2093-2107

> Tremaine SC, Mills A (1987) Tests of the critical assumptions of the dilution method for estimating bacterivory by microeucaryotes. Appl Environ Microbiol 53:2914-2921

> Troussellier M, Got P, Mboup M, Corbin D, Giuliano L, Cappello S, Bouvy M (2005) Daily bacterioplankton dynamics in a sub-Saharan estuary (Senegal River, West Africa): a mesocosm study. Aquat Microb Ecol 40:13-24

- Turley CM, Bianchi M, Christaki U, Conan P and others (2000) Relationship between primary producers and bacteria in an oligotrophic sea - the Mediterranean and biogeochemical implications. Mar Ecol Prog Ser 193:11-18

Utermöhl H (1958) Zur Vervollkommnung der quantitativen Phytoplankton-Methodik. Mitt Int Ver Theor Angew Limnol 9:1-38

> Vaqué D, Gasol JM, Marrasé C (1994) Grazing rates on bacteria: the significance of methodology and ecological factors. Mar Ecol Prog Ser 109:263-274

Verity PG, Langdon C (1984) Relationships between lorica volume, carbon, nitrogen, and ATP content of tintinnids in Narragansett Bay. J Plankton Res 6:859-868

- Weinbauer MG, Höfle MG (1998a) Significance of viral lysis and flagellate grazing as factors controlling bacterioplankton production in a eutrophic lake. Appl Environ Microbiol 64:431-438

Weinbauer MG, Höfle MG (1998b) Size-specific mortality of lake bacterioplankton by natural virus communities. Aquat Microb Ecol 15:103-113

> Weinbauer MG, Brettar I, Höfle MG (2003) Lysogeny and virus-induced mortality of bacterioplankton in surface, deep, and anoxic marine waters. Limnol Oceanogr 48: $1457-1465$

Wen K, Ortmann AC, Suttle CA (2004) Accurate estimation of viral abundance by epifluorescence microscopy. Appl Environ Microbiol 70:3862-3867

Wilhelm SW, Brigden SM, Suttle CA (2002) A dilution technique for the direct measurement of viral production: a comparison in stratified and tidally mixed coastal waters. Microb Ecol 43:168-173

- Wommack KE, Colwell RR (2000) Virioplankton: viruses in aquatic ecosystems. Microbiol Mol Biol Rev 64:69-114

Worden AZ, Binder BJ (2003) Application of dilution experiments for measuring growth and mortality rates among Prochlorococcus and Synechococcus populations in oligotrophic environments. Aquat Microb Ecol 30:159-174

Yokokawa T, Nagata T (2005) Growth and grazing mortality rates of phylogenetics groups of bacterioplankton in coastal marine environments. Appl Environ Microbiol 71: 6799-6807

Submitted: December 16, 2009; Accepted: September 6, 2010 Proofs received from author(s): November 5, 2010 